\title{
Video as a Tool in Improving Pharmacy Student's Knowledge and Skills About Tonicity
}

\author{
Uswatul Hasanah $^{1 *}$, Lili Fitriani ${ }^{1}$, Erizal Zaini ${ }^{1}$

\begin{abstract}
${ }^{1}$ Department of Pharmaceutics, Faculty of Pharmacy, Universitas Andalas
\end{abstract} \\ *Corresponding author. Email: uswatulhasanah@phar.unand.ac.id
}

\begin{abstract}
The COVID-19 pandemic has transformed in-class courses into the online class. A web-conference software program was mostly used to deliver the learning activity. But this method was ineffective due to lack of cognitive engagement. This study aims to improve students' ability to solve the tonicity problems by using videos. Two videos were used as a media to learn tonicity, both theory and the calculation. The students previously studied tonicity by joining the webconference and took a pre-test to measure the baseline score. Then, the students were free to access the videos for 5 hours and took a post-test. The mean of the total score, theoretical score, and calculation skill score was analysed statistically. The results show a significant increase in the average total score, cognitive score and skill score by 51.38 , 35.23 , and $71.62 \%$, respectively. In conclusion, the lecturer can use videos as a tool to improve the learning activity.
\end{abstract}

Keywords: pharmacy, pharmaceutical calculation, tonicity, video

\section{INTRODUCTION}

SARS-CoV-2 started to spread from Wuhan, China, in December 2019 and was rapidly transmitted to several countries until WHO declared that the world is encountering a global health crisis as COVID-19 pandemic. The Indonesian government ordered every citizen to limit physical interaction and keep personal hygiene to prevent COVID-19 infection. To ensure the safety of each person in the institution, most of them implement the work-from-home system. Teaching and learning activities at university must adapt to the new condition due to COVID-19 pandemic since early 2020. Lecturers could not use the conventional learning method applied in the previous semester since it gathered many people in the same room, and it could increase the risk of transmission of the COVID-19. Thus, lecturers held a remote teaching and learning activity on an online platform.

Using technology in teaching and learning activities seem applicable to support and build the student's knowledge and skills, especially in this COVID-19 pandemic [1-5]. Many universities use web conference program to transform the offline teaching format to online format. Butz et.al investigated the students' satisfaction and achievement of online class compared to the opposite form. The data indicated that the web conference based class is not as effective as conventional in-class activity [6]. Cognitive engagement is one of the aspects that affect the effectiveness of a course. In the transition to the online class, cognitive engagement seems lower than the offline class [7]. The lecturers need to prepare tools that also manageable by the students [7]. Bruggeman reveals that the implementation of blended learning in university is influenced by the teacher's mindset [8]. Teachers' creativity is needed to improve student motivation in online classroom $[9,10]$.

Universitas Andalas provided the online Learning Management System as iLearn (Moodle) that can be accessed by all students and lecturers. This platform offers various activities needed in learning and teaching activity such as learning material file attachment, video embedding, a quiz with several types of question form, SCORM support for an interactive learning process, assignment, and a discussion room. The features are suitable to be used in online courses. In this research, some videos are prepared to support the synchronous session.

Online course contents seem like a promising way to deliver teaching materials included in pharmacy education [11]. Video could be used in improving and enhancing learning activities-for example, a prerecorded lecture intervention to some courses providing improved skill and student performance in 
pharmaceutics, science, and clinical pharmacy [12-17]. For some people, learning calculations require repetition, and a recorded video meets this condition. Due to those research, the optimal video length to disseminate some information is around 18 minutes[13,17-19].

Sterile Dosage Form Technology course contents are about how to produce a good quality of injection and ocular dosage form. One of the course learning outcomes (CLO) is the students are able to analyze the tonicity of formula and solve the tonicity problem. This topic consists of a theory of tonicity and several tonicity calculation method. In the previous year, this particular CLO did not meet the target. Some of the students exhibit low performance in laboratory activity to design a sterile dosage form, especially about the tonicity. The pandemic condition required a limitation in social interaction; therefore, the lecturer could not directly explain and teach the students. This study aims to evaluate the effectiveness of videos intervention in students' performance.

\section{EDUCATIONAL ACTIVITY AND SETTING}

This research was a quasi-experimental comparative study using pre-test and post-test with two videos about tonicity as the intervention.

Participants are the students of the Undergraduate Pharmacy Study Programme (UPSP) of Universitas Andalas enrolled in the Sterile Dosage Form Technology course (FAF 311) on iLearn $(n=134)$.

The Sterile Dosage Form Technology course is a 14 week course to teach the students how to make a good quality sterile dosage form. One of the contents in this course syllabus is tonicity. Counting the tonicity is the basic skill to do the laboratory practice to calculate an injection or ocular dosage form formula. Thus, the teaching team allocated this module for two weeks.

This research intervention is in the form of videos prepared in 2 different topics, each for theory and tonicity calculation. In the first week, the students learned tonicity by joining the web conference and doing the assignment. The students learn about tonicity directly from the lecturer and self-learning by doing the task. Next week, the pre-test was administered to evaluate the students' skills and knowledge from the previous learning activity. The post-test would be unlocked after students got a grade for the pre-test and watched the videos.

The pre-test and post-test questions were created according to the Sterile Dosage Form Technology course learning outcome. Eight items were designed to assess the theoretical knowledge and seven questions to evaluate the calculation skill.

The pre-test scores, post-test, theory, and calculation skill scores were analyzed statistically using paired ttest performed in Microsoft Excel 2016 (p<0.05).

\section{FINDINGS}

Tonicity is a crucial factor in formulating a sterile dosage form. Since most sterile dosage forms would be produced as an injection, a hypotonic or extremely hypertonic formula would affect the body homeostatic. Therefore, a pharmacist, or specifically in this study, an undergraduate pharmacy student, should adjust the formula's tonicity to produce a sterile dosage form. Tonicity of a solution was related to its osmolarity in comparison with body fluid osmolarity, i.e. blood and lacrimal fluid. Tonicity can be calculated by various methods and formulas that used the same variables. Based on the previous class in 2019, those theories and formulas were frequently mixed up by the students, and they cannot give an isotonic formula.

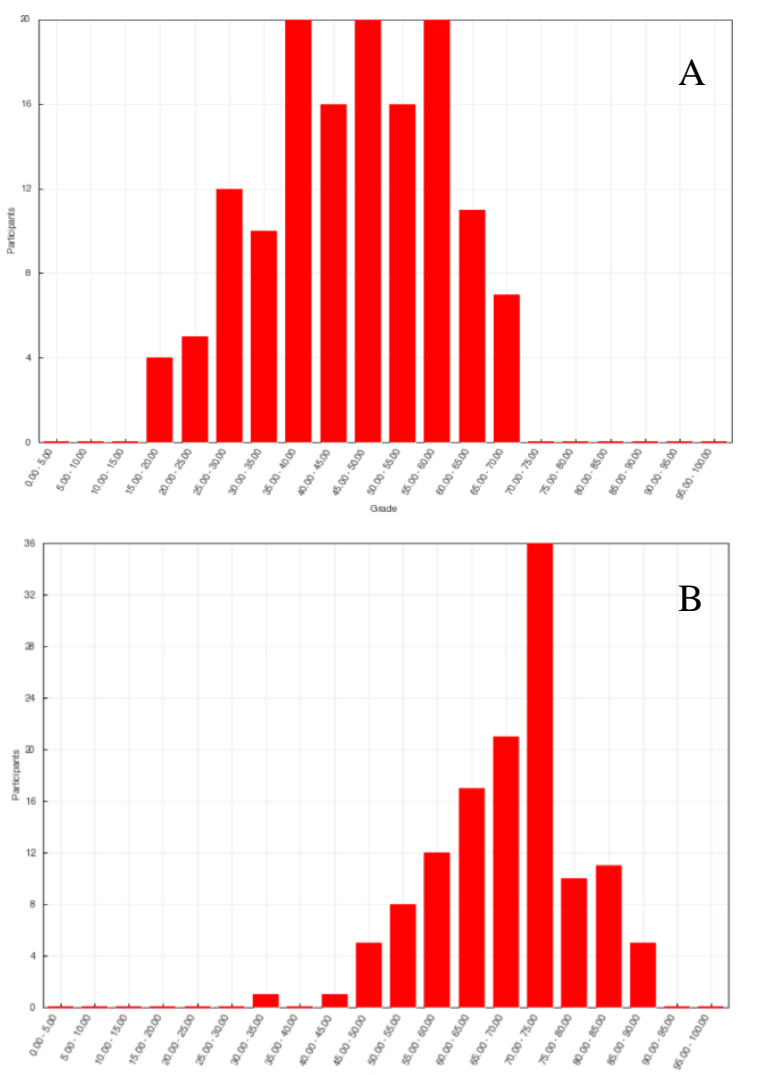

Figure 1. Score distribution of pre-test (A) and posttest (B) with tonicity video intervention $(n=134)$

As stated in the previous section, this study participants are 134 students of UPSP enrolled in the Sterile Dosage Form course on ilearn. Every test, learning material and 
intervention were provided on iLearn. Figure 1 presented the score distribution of the pre-test and posttest. Overall, the score distribution chart showed a normal bell-shaped distribution pattern. The bars are visually seen to be shifting to the right that indicates increasing for the post-test result.

Table 1. Score of pre-test and post-test with video

\begin{tabular}{llllll}
\hline Score Criteria & Mean & SD* & Min & Max & $\begin{array}{l}\text { Paired t- } \\
\text { test }\end{array}$ \\
\hline Pretest (n=15) & 44.82 & $\begin{array}{l}12.4 \\
3\end{array}$ & $\begin{array}{l}18.8 \\
9\end{array}$ & 69.44 & $1.2 \times 10^{-40}$ \\
Post-test (n=15) & 67.85 & $\begin{array}{l}10.0 \\
5\end{array}$ & $\begin{array}{l}31.6 \\
7\end{array}$ & 87.78 & \\
$\begin{array}{l}\text { Theory questions } \\
\text { (n=8) - Pretest }\end{array}$ & 25.44 & 8.55 & 6.67 & 46.69 & $9.7 \times 10^{-19}$ \\
$\begin{array}{l}\text { Theory questions } \\
\text { (n=8) - Post-test }\end{array}$ & 34.40 & 6.76 & 13.3 & 46.69 & \\
$\begin{array}{l}\text { Calculation skill } \\
\text { questions (n=7) - }\end{array}$ & 19.51 & 6.91 & 5.00 & 36.12 & $1.1 \times 10^{-40}$ \\
$\begin{array}{l}\text { Pretest } \\
\text { Calculation skill }\end{array}$ & & & & & \\
questions (n=7) - & 33.48 & 6.49 & 16.1 & 41.12 & \\
\begin{tabular}{l} 
Post-test \\
\hline
\end{tabular} & & & 1 & & \\
\hline
\end{tabular}

intervention in Steril Dosage Form Technology course

Note: Each score criteria counted for a total 134 students and statistical analysis was subjected to each students' pre and post-test score. *SD: Standard deviation

More details of the numerical data on the pre-test and post-test scores are presented in table 1. Based on the mean data, an increase in the overall score, theoretical ability, and calculation skills was 51.38, 35.23 , and $71.62 \%$, respectively. This result is in line with the t-test statistical analysis results, which gave a value of $\mathrm{p}<0.05$, so statistically, there was a significant change in students' theoretical understanding and skills before and after the intervention.

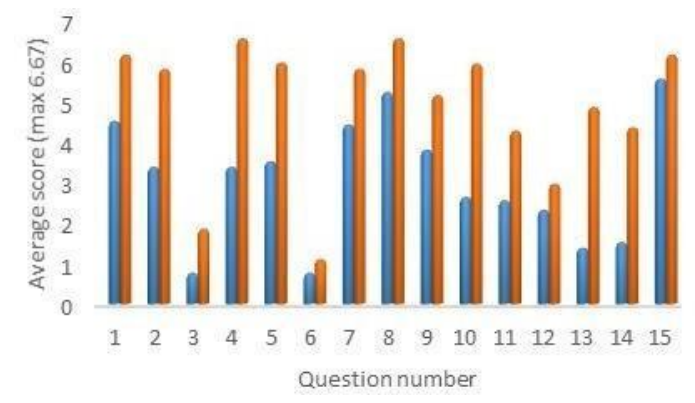

Figure 2. Pre-test (blue) and post-test (orange) score distribution by the question
Based on each item score, all questions show an increase in the average score after the intervention, especially in items number 10-14, which are part of the calculation questions. A noticeable increase occurs in item number 13 , which is related to students' ability to determine the reference data that need to be used in tonicity calculations.

\section{DISCUSSION}

This study showed that online self-learning from videos contains a particular topic significantly improved the assessment score of knowledge and skill. The students were previously learned in a conventional teaching method using a web conference, and most of them scored less than 50 points. The calculation question gave lower scores. This result is in line with the theory that calculation skills might need repetition to understand the step entirely $[17,19]$. Thus, this intervention facilitated the student to rewatch the steps until they fully understand how to calculate the tonicity. These findings contribute to advancing online learning method in the Faculty of Pharmacy, Universitas Andalas. Additionally, in just less than one-day intervention, this study showed a significant improvement of students` course learning outcomes in Sterile Dosage Form Technology. This is aligned with the implementation of Outcome Based Education (OBE) in Indonesia.

In terms of cognitive engagement, this method provides a good example. The media used, a video, was preferred by the students. Wong et.ar did a research about the media preferred by the students between a voice-over power point and web conference recording, and the former gain most of the votes [19].

Moreover, the students are expected to have a good analysis in formulating an injection in laboratory activity in the next few months. Since they can calculate a formula's tonicity, they would come with a more rational and isotonic formula.

\section{CONCLUSION}

The score comparison between the pre-test and posttest with video intervention shows positive results regarding student performance in understanding the tonicity module, both theory and calculation skill. This method can be applied to other Undergraduate Pharmacy Study Program classes to fulfil the course learning outcome. This online learning system may be optimally implemented to deliver learning activity in the COVID-19 pandemic. 


\section{AUTHORS' CONTRIBUTIONS}

Erizal Zaini, Lili Fitriani, and Uswatul Hasanah contributed to the study design and implementation, data analysis, and the manuscripts' writing.

\section{ACKNOWLEDGMENTS}

We thank Lembaga Pengembangan Pendidikan dan Penjaminan Mutu (LP3M) Universitas Andalas for funding our research through Program Pengembangan Blended Learning (PPBL). This article is an output to educational grant T.011/UN.16.18/ PT.01.03/2020.

\section{REFERENCES}

[1]. Forbes H, Oprescu FI, Downer T, Phillips NM, McTier L, Lord B, et al. Use of videos to support teaching and learning of clinical skills in nursing education: A review. Nurse Educ Today. 2016;42:53-6.

https://doi.org/https://doi.org/10.1016/j.nedt.201 $\underline{6} .04 .010$

[2]. Ellis RA, Pardo A, Han F. Quality in blended learning environments - Significant differences in how students approach learning collaborations. Comput Educ.

$$
\text { 2016;102:90-102. }
$$

https://doi.org/https://doi.org/10.1016/j.comped u. 2016.07.006

[3]. Huang C-Q, Han Z-M, Li M-X, Jong MS, Tsai C-C. Investigating students' interaction patterns and dynamic learning sentiments in online discussions. Comput Educ.

$$
\text { 2019;140:103589. }
$$

https://doi.org/https://doi.org/10.1016/j.comped u. 2019.05 .015

[4]. Post LS, Guo P, Saab N, Admiraal W. Effects of remote labs on cognitive, behavioral, and affective learning outcomes in higher education. Comput Educ. 2019;140:103596. https://doi.org/https://doi.org/10.1016/j.compedu. 2019.103596

[5]. Yang J, Yu H, Chen N. Using blended synchronous classroom approach to promote learning performance in rural area. Comput Educ. 2019;141:103619. https://doi.org/https://doi.org/10.1016/j.compedu. 2019.103619

[6]. Butz NT, Stupnisky RH. A mixed methods study of graduate students' self-determined motivation in synchronous hybrid learning environments. Internet High Educ. 2016;28:85-95. https://doi.org/https://doi.org/10.1016/j.iheduc.2 015.10 .003
[7]. Patricia A. College Students' Use and Acceptance of Emergency Online Learning Due to COVID-19. Int $\mathrm{J}$ Educ Res Open. 2020;100011.

https://doi.org/https://doi.org/10.1016/j.ijedro.20 20.100011

[8]. Bruggeman B, Tondeur J, Struyven K, Pynoo B, Garone A, Vanslambrouck S. Experts speaking: Crucial teacher attributes for implementing blended learning in higher education. Internet High Educ. 2020;100772. https://doi.org/https://doi.org/10.1016/j.iheduc.20 20.100772

[9]. Nazarenko AL. Blended Learning vs Traditional Learning: What Works? (A Case Study Research). Procedia - Soc Behav Sci. 2015;200:77-82.

https://doi.org/https://doi.org/10.1016/j.sbspro.20 15.08.018

[10]. Rahman NAA, Hussein N, Aluwi AH. Satisfaction on Blended Learning in a Public Higher Education Institution: What Factors Matter? Procedia - Soc Behav Sci. 2015;211:76875. https://doi.org/https://doi.org/10.1016/j.sbspro.20 15.11.107

[11]. Hamilton LA, Suda KJ, Heidel RE, McDonough SLK, Hunt ME, Franks AS. The role of online learning in pharmacy education: A nationwide survey of student pharmacists. Curr Pharm Teach Learn.2020;12(6):614-25.

https://doi.org/https://doi.org/10.1016/j.cptl.2020 .01 .026

[12]. Missildine K, Fountain R, Gosselin K. Flipping the Classroom to Improve Student Performance and Satisfaction. J Nurs Educ. 2013;52:1-3. https://doi.org/10.3928/01484834-20130919-03

[13]. Cotta K, Shah S, Almgren M, Macias-Moriarity L, Mody V. Effectiveness of flipped classroom instructional model in teaching pharmaceutical calculations. Curr Pharm Teach Learn. 2016;8. https://doi.org/10.1016/j.cptl.2016.06.011

[14]. McLaughlin JE, Griffin LM, Esserman DA, Davidson CA, Glatt DM, Roth MT, et al. Pharmacy student engagement, performance, and perception in a flipped satellite classroom. Am J Pharm Educ. 2013;77(9):196. https://doi.org/10.5688/ajpe779196

[15]. McLaughlin JE, Roth MT, Glatt DM, Gharkholonarehe N, Davidson CA, Griffin LM, et al. The flipped classroom: a course redesign to foster learning and engagement in a health professions school. Acad Med. 2014;89(2):23643.

https://doi.org/10.1097/ACM.000000000000008 $\underline{6}$ 
[16]. Pierce R, Fox J. Vodcasts and activelearning exercises in a "flipped classroom" model of a renal pharmacotherapy module. Am J Pharm Educ. 2012;76(10):196. https://doi.org/10.5688/ajpe7610196

[17]. Newsom L, Proctor R, Marshall LL, Liao TV. Implementation and evaluation of problembased video podcasts in an introductory pharmacokinetics course. Curr Pharm Teach Learn. 2019;11(12):1213-20. https://doi.org/https://doi.org/10.1016/j.cptl.201 9.09.003

[18]. Rashid M, Rahman M, Nounou M, Islam MA. Speed and accuracy of pharmacy students' response to calculation problems with or without formula prompts. Curr Pharm Teach Learn. 2020;

https://doi.org/https://doi.org/10.1016/j.cptl.202 0.08 .007

[19]. Gloudeman MW, Shah-Manek B, Wong TH, Vo C, Ip EJ. Use of condensed videos in a flipped classroom for pharmaceutical calculations: Student perceptions and academic performance. Curr Pharm Teach Learn. 2018;10(2):206-10.

https://doi.org/https://doi.org/10.1016/j.cptl.201 7.10 .001 